Acta Universitatis Lodziensis

www.czasopisma.uni.lodz.pl/foe/

3(335) 2018

DOI: http://dx.doi.org/10.18778/0208-6018.335.04

\title{
Adrianna Mastalerz-Kodzis
}

University of Economics in Katowice, Faculty of Management, Department of Statistics,

Econometrics and Mathematics, adrianna.mastalerz-kodzis@ue.katowice.pl

\section{Ewa Katarzyna Pośpiech}

University of Economics in Katowice, Faculty of Management, Department of Statistics,

Econometrics and Mathematics, ewa.pospiech@ue.katowice.pl

\section{Application of Hölder Function to Expansion Intensity of Spatial Phenomena Analysis}

\begin{abstract}
The development of methods describing time series using stochastic processes took place in the $20^{\text {th }}$ century. Among others, stationary processes were modelled with Hurst exponent, whereas non-stationary processes with Hölder function. The characteristic feature of this type of processes is the analysis of the memory present in the time series. At the turn of the $21^{\text {st }}$ century interest in statistics and spatial econometrics, as well as analyses carried out within the new economic geography arose. In this article, we have proposed the implementation of methods taken from the analysis of time series in the modelling of spatial data and the application of selected measures in studying the intensity of expansion in spatial phenomena. As the intensity measure we use Hölder point exponents. The article is composed of two parts. The first one contains the description of study methodology, the second - examples of application.
\end{abstract}

Keywords: stochastic process, Hurst exponent, Hölder function, spatial modelling

JEL: C15, C32, C33, C51 


\section{Introduction}

Economy changes in a dynamic and stochastic way, therefore methods used in the description of phenomena and processes taking place within the socio-economic context should also be dependent on time and contain an element of randomness. Due to a common access to panel data, the methodology developed for time series can be applied in temporal and spatial analyses.

In the article we have connected two types of modelling approach.

The first is the use of stationary and non-stationary stochastic processes containing Brownian motion processes. Stochastic models have become a permanent feature of the econometrics field and the intensive development of this methodology took place in econometric and time series analysis literature at the end of the $20^{\text {th }}$ century. The following works are examples of time series analysis range: Box, Jenkins (1976), Granger, Mizon (1994), Fuller (1996), and in these time series are modelled as realizations of fractional and multi-fractional Brownian motion processes: Mandelbrot (1982), Peters (1994), Ayache, Lévy-Véhel (1999).

The $21^{\text {st }}$ century also witnessed a dynamic development of statistics and spatial econometrics (Kopczewska, 2007; Suchecki, 2010; Domański, 2002; Zeliaś, 1991; Paelinck, Klaassen, 1983; Matyas, Sevestre, 2006; Hsiao, 2003; Getis, Mur, Zoller, 2004; Baltagi, 2005). The field of economics which is undoubtedly represented by the New Economic Geography (NEG) belongs to the second trend of study. At the turn of the $21^{\text {st }}$ century an interest in the NEG arose, quantitative methods were applied in methodology (Krugman, 1991); trend surface analysis, diffusion (Hagerstrand, 1952; Bass, 1969), gravity and potential appeared.

The article describes an implementation of methods taken from time series analysis used in modelling data in space and generalisation of methods for the multivariate case (Lévy-Véhel, Mendivil, 2011; Falconer, Lévy-Véhel, 2008; Lévy-Véhel, Seuret, 2004; Ayache, Taqqu, 2004; Barrière, 2007; Echelard, Barrière, Lévy-Véhel, 2010).

The aim of the article is the application of Hölder function in the study of the expansion intensity of spatial phenomena. The research hypothesis can therefore be expressed as follows: it is assumed that Hölder point exponents can be interpreted as the intensity of expansion of spatial phenomena.

\section{Elements of the methodology of time series analysis}

In the process of time series modelling using fractional and multi-fractional processes of Brownian motion, time is the only argument. Stationary processes which 
are featured by fractional parts of Brownian motion depend on a constant parameter - Hurst exponent. This exponent belongs to the range $(0,1)$ and divides the time series into: persistent - with a positive correlation between the subsequent implementations $(H \in(1 / 2,1))$ and anti-persistent, in which the correlation is negative $(H \in(0,1 / 2))$. A general case is considered below - processes dependent on Hölder function. Fractional processes are an exceptional example of multi-fractional ones, that is, a constant Hölder function is the value of Hurst exponent.

\subsection{Definition of Hölder function}

Let $\left(X, d_{X}\right)$ and $\left(Y, d_{Y}\right)$ be metric spaces (Daoudi, Lévy-Véhel, Meyer, 1998; Mastalerz-Kodzis, 2003). Function $f: X \rightarrow Y$ is called Hölder function with an exponent $\alpha(\alpha>0)$, if for each $x, y \in X$ such, that $d_{X}(x, y)<1$ the function fulfils the inequality with a positive constant $c$ :

$$
d_{Y}(f(x), f(y)) \leq c \cdot\left(d_{X}(x, y)\right)^{\alpha} .
$$

Hölder function is by definition a continuous function in the range. If the function is of class $C^{1}$ then the fractional value of the function graph equals one. When we only assume that the function is of class $C^{0}$, then the graph can feature a fractional measure.

Let there be a function $f: D \rightarrow \Re(\mathrm{D} \subset \Re)$ and parameter $\alpha \in(0,1)$. Function $f: D \rightarrow \Re$ is Hölder function of class $C \alpha(f \in C \alpha)$, if there are constants $c>0$ and $h_{0}>0$ such, that for each $x$ as well as all of $h$ such, that $0<h<h_{0}$ the following inequality is fulfilled:

$$
|f(x+h)-f(x)| \leq c h^{\alpha} .
$$

Let $x_{0}$ be any point from the function range $f\left(x_{0} \in D \subset \Re\right)$. Function $f: D \rightarrow$ $\Re$ is at point $x_{0}$ Hölder function of class $C_{x_{0}}^{\alpha}\left(f \in C_{x_{0}}^{\alpha}\right)$, if there are constants $\varepsilon$, $c>0$ such, that for each $x \in\left(x_{0}-\varepsilon, x_{0}+\varepsilon\right)$ the following inequality is fulfilled:

$$
\left|f(x)-f\left(x_{0}\right)\right| \leq c\left|x-x_{0}\right|^{\alpha}
$$

Hölder point exponent of function $f$ at point $x_{0}$ is the number $\alpha_{f}\left(x_{0}\right)$ expressed by the formula $\alpha_{f}\left(x_{0}\right)=\sup \left\{\alpha: f \in C_{x_{0}}^{\alpha}\right\}$. The Hölder function for function $f$ is the function, which to each of the points $x \in D$ assigns the number $\alpha_{f}(x)$. 


\subsection{Stochastic process dependent on Hölder function}

Let $H_{i}:[0, \infty) \rightarrow(0,1)$ be the Hölder function with an exponent $\alpha>0$. A multi-fractional Brownian motion process with a function parameter $H_{t}$ is a stochastic process $B_{H_{t}}(t)$ defined for $t \geq 0$ by the formula (Ayache, Lévy-Véhel, 1999; Peltier, Lévy-Véhel, 1995):

$$
B_{H t}(t)=\frac{1}{\Gamma\left(H_{t}+\frac{1}{2}\right)}\left\{\int_{-\infty}^{0}\left[(t-s)^{H_{t}-1 / 2}-(-s)^{H_{t}-1 / 2}\right] d B(s)+\int_{0}^{t}(t-s)^{H_{t}-1 / 2} d B(s)\right\},
$$

where $B$ is the standard Brownian motion process.

The Hölder point exponents inform one about the characteristics of the process (Ayache, Lévy-Véhel, 1999; Daoudi, Lévy-Véhel, Meyer, 1998). Among others, we can note that the process does not feature stationary growths when Hölder function is not constant and the closer the values of the function are to zero the bigger the variability of the graph. For function values close to one the process is smoother. The local capacitive and Hausdorff value of the process trajectory $B_{H_{t}}(t)$ for each $t_{0} \geq 0$ equals $2-H\left(t_{0}\right)$ and with probability equal to one Hölder point exponent of the process trajectory $B_{H}(t)$ for each $t_{0} \geq 0$ equals $H\left(t_{0}\right)$. The regularity of the process measured with Hölder point exponents changes in the range $(0,1)$.

In the multi-fractional Brown's motion process Hölder function is a constant function, which means that the regularity of the process trajectory measured by this function also changes continuously. Further generalisation of Brown's motion process is based on the replacement of the continuous Hölder function with a discontinuous one (Peltier, Lévy-Véhel, 1995). A generalised multi-fractional Brown's motion process with function parameter $H(t)$ and $\lambda-$ a real number is process $\left\{B_{H} \lambda(t)\right\}_{t} \in \Re$ such, that for each $t \in \mathfrak{R}$ :

$$
B_{H, \lambda}(t)=\sum_{n=0}^{\infty} \int_{D_{n}} \frac{e^{i t \xi}-1}{|\xi|^{H_{n}(t)+\ddot{u}}} d B(\xi),
$$

where $D_{0}=\{\xi:|\xi|<1\}$ and for all $n \geq 1 D_{n}=\left\{\xi: \lambda^{\mathrm{n}-1} \leq|\xi|<\lambda^{\mathrm{n}}\right\}$.

\subsection{Multi-fractional Brownian motion process generation method - method of random relocation of the segment midpoint}

The multi-fractional Brownian motion process can be generated with the use of random relocation of the segment midpoint method (Mastalerz-Kodzis, 2003; 2016). 

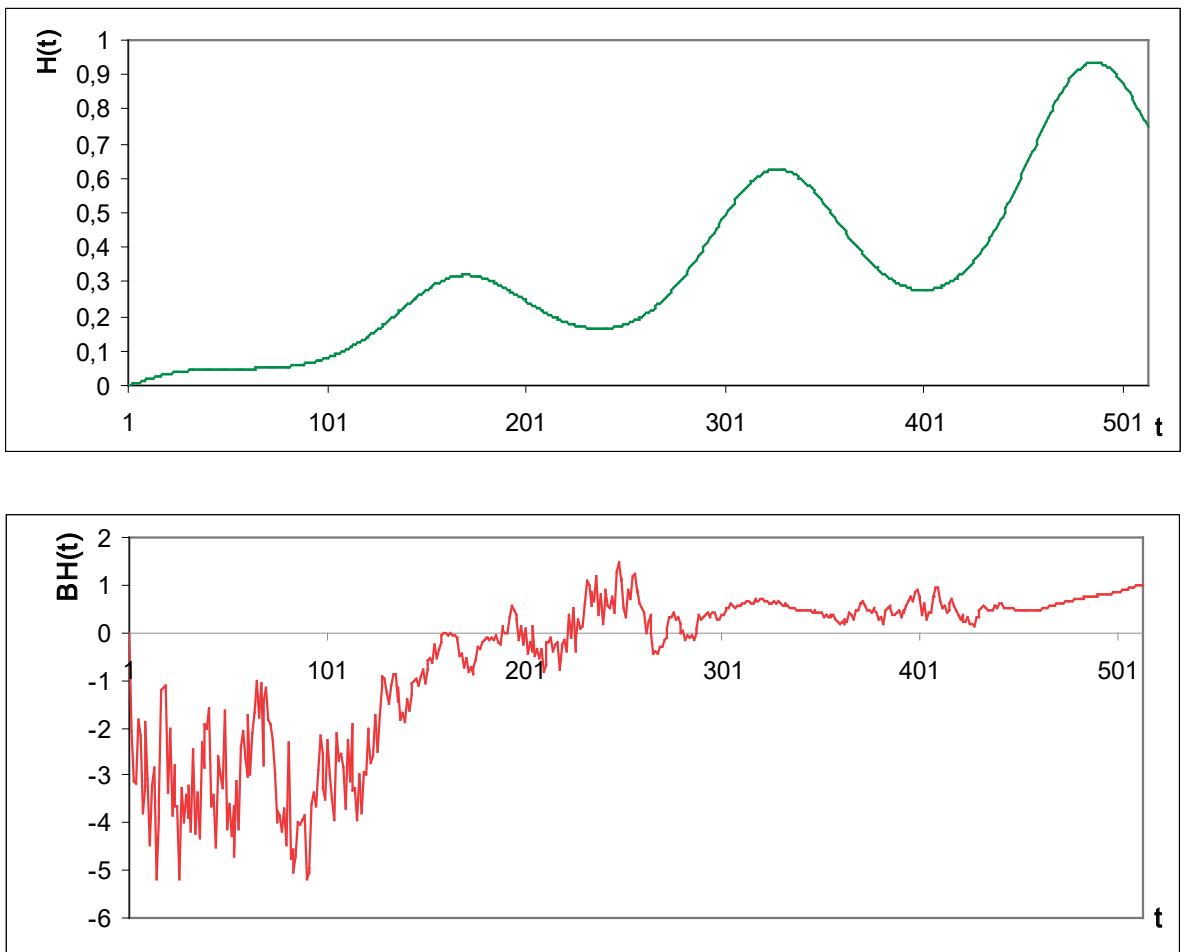

Figure 1. Multi-fractional Brownian motion process: Hölder function in form $H(t)=0,9 t\left(\cos \left(\sin (10 t)^{2}\right)+0,1\right)$, process simulation for the set function $H(t)$

Source: own study

Interval $[0,1]$ is divided at half point and the following value is assigned to it

$$
B_{H(1 / 2)}(1 / 2)=\frac{B(0)+B(1)}{2}+G \frac{\sqrt{1-2^{2^{*} H(1 / 2)-2}}}{2^{1^{*} H(1 / 2)}},
$$

where $B(0)=0, B(1)$ is equal to Gaussian pseudorandom number with a mean of 0 and variation of 1 . Value $H(1 / 2)$ is set, whereas $G$ in the subsequent stages is a series of pseudorandom numbers, which constitute an implementation of a variable of a normal distribution $N(0,1)$.

Generally, also in this stage, the value of the process is set by the formula

$$
B_{H(t)}(t)=\frac{B(t-d)+B(t+d)}{2}+G \frac{\sqrt{1-2^{2 H(t)-2}}}{2^{i^{*} H(t)}},
$$

where $t-d$ and $t+d$ are the former points of time segment interval [0, 1] (see Figure 1). 


\section{Elements of new economic geography}

NEG is a field of science and economics dealing with spatial aspects, among others localization of economic activity in the world (Suchecki, 2010). In the $21^{\text {st }}$ century, the consideration of e.g. the results of globalization phenomenon or environmental pollution is possible, among others, with the use of NEG methods. It is considered that space (geographic location, distance, neighbourhood) has a significant influence on the formation of a given phenomenon or an economic process. Krugman (1991) started the development of quantitative methods in NEG. The aim of this field of science is the explanation of concentration and agglomeration or dispersion of economic phenomena within geographic space. Spatial distribution (allocation) of economic activities is treated as an endogenous factor. In numerous studies it has been proved that geographic activities are not evenly distributed in space. Their intensity depends on many factors, which should be specified through the use of models.

In NEG we can distinguish among others:

1. Cause and effect models (spatial interactions e.g. the influence of European integration on international commerce); the answer to the question: where do economic activities concentrate and what is the reason for this in the era of globalization.

2. Spatial models, where independent variables constitute the coordinates of geographical location or the distance from a certain fixed point. Model parameters inform one about the force and the direction of regional tendencies in the development of spatial structure of the phenomenon.

3. Spatial diffusion models (deterministic and stochastic), used in carrying out analyses concerning transfer - shifting of socio-economic phenomena in space e.g.: relocation of population, knowledge, information, innovation, diseases (Hagerstrand, 1952; Bass, 1969). Hagerstrand proved that the probability of diffusion is a decreasing function of distance and that diffusion processes are multivariate (that is, they spread from one area to another, and subsequently, with a certain delay, to further areas). We can distinguish, among others: expansive, relocating, contagious and hierarchical diffusion (Suchecki, 2010).

4. Models of gravity, gravitation and potential, used, inter alia, in the analysis of the migration of population, the spatial variability of economic characteristics (e.g. incomes) and in analyses of spatial interaction between objects. 


\section{The application of Hölder function in spatial analyses}

The Hölder function, defined in chapter 2.1 is dependent only on parameter $t$ and it is responsible for the variability of a process around any point in the range. Stochastic process can therefore be presented by a two-dimensional coordinate system. However, taking into consideration the NEG approach, we can question the application of methodology from chapter 2 to spatial economic analyses, conditioning the analyses on specific points in space and taking into consideration the memory effect. In NEG it was also Hagerstrand (1991) that drew his attention to the aspect of memory in the spreading of phenomena in space.

In literature (Ayache, Taqqu, 2004; Barrière, 2007; Echelard, Barrière, Lévy-Véhel, 2010; Falconer, Lévy-Véhel, 2008; Lévy-Véhel, Mendivil, 2011) the expansion of analyses for the multidimensional case is applied in analyses of image compression.

Therefore, generalizing to multivariate case, Hölder function is dependent on time $t$, and also on a point on a plane $(x, y)$. Therefore, we obtain function $H_{t}(x, y)$ for $\alpha>0$ and process $B_{\ddot{u}_{t}(,)_{i} \lambda}(x, y, t)$.

Two-dimensional, fractional Brownian motion with fixed Hölder function (with Hurst exponent) is a stationary stochastic process for each $(x, y) \in R$ with an expected covariance expressed by the formula:

$$
E\left(B_{H}(x), B_{H}(y)\right)=\|x\|^{2 H}+\|y\|^{2 H}-\|x-y\|^{2 H} .
$$

Let $H$ be a continuous function. Two-dimensional, multi-fractional Brownian motion process is a stationary or non-stationary stochastic process with covariance function expressed by the formula:

$$
E\left(B_{H(.)}(x), B_{H(.)}(y)\right)=\|x\|^{H(x)+H(y)}+\|y\|^{H(x)+H(y)}-\|x-y\|^{H(x)+H(y)} .
$$

The Hölder exponent measures the regularity of the function graph. If we assume that $H$ is a differentiable function then, with probability 1 for each $(x, y)$, equality $\alpha_{B_{H(x, y)}}(x, y)=H(x, y)$ takes place.

\subsection{Generalised method of random relocation of the segment midpoint}

Similarly as in the single-dimensional case, there exists a method of generating three-dimensional surfaces (Perfect, Tarquis, Bird, 2009; Mastalerz-Kodzis, 2016). When generating a coast line, we draw a polyline within a two-dimensional area, 
whereas while generating mountain ranges, we create a three-dimensional area. The base of the algorithm is a recurrent area division into smaller areas of the same shape. These areas can be represented by any shapes e.g. squares, triangles or hexagons. Randomly, we assign the heights at which the nodes of the shapes will be placed and then we must calculate the heights of the points needed for the next division. We calculate the average height of the neighbouring points and modify it by random value. Further, having calculated the new heights, we use them as nodes for the new shape, which is divided once again. A square is divided into four squares, a triangle into four triangles and a hexagon into three hexagons and for each of them the whole algorithm is repeated, decreasing the maximum value of the random height modification.

To each of the objects formed in this way we assign a measure (intensity), whose definition is based on the set parameter $\mathrm{H}(0<H<1)$ or $H(t)(0<H(t)<1)$ and on Newton's binomial. After defining the values of the measures, their layout in the sector formed as a result of the division is random in each stage of iteration.

Let's consider a three-dimensional coordinate system. On the plane XY we place a square with side equal to 1 . The Brownian process at moment $t$ assigns value $z$ for argument $(x, y)$ and for value $H(x, y)$. Value $z$ is dependent on Hurst exponent or Hölder function.

The first iterative stage of generating the multi-fractional Brownian motion process in space can be expressed by the following formula:

$$
B_{H_{t}(x, y), \lambda}(x, y, t)=\frac{B_{t-1}\left(x_{1}, y_{1}\right)+B_{t-1}\left(x_{2}, y_{2}\right)}{2}+G \frac{\sqrt{1-2^{2 H_{t}(x, y)-2}}}{2^{i^{* * H_{t}(x, y)}}} .
$$

Where $\left(x_{1}, y_{1}\right),\left(x_{2}, y_{2}\right)$ are the former division points, $H(x, y)$ is the value of Hölder function for argument $(x, y)$, whereas $G$ in the subsequent stages is a series of pseudorandom numbers which constitute an implementation of a variable with a normal distribution $N(0,1)$.

In Figure 2 we have illustrated the implementation of the first four recurrent stages for the set generating function $H(x, y)$. Variable $z$, which is the value of the process in space is represented in the bubble chart by the diameter of a circle with a set centre $(x, y)$. 


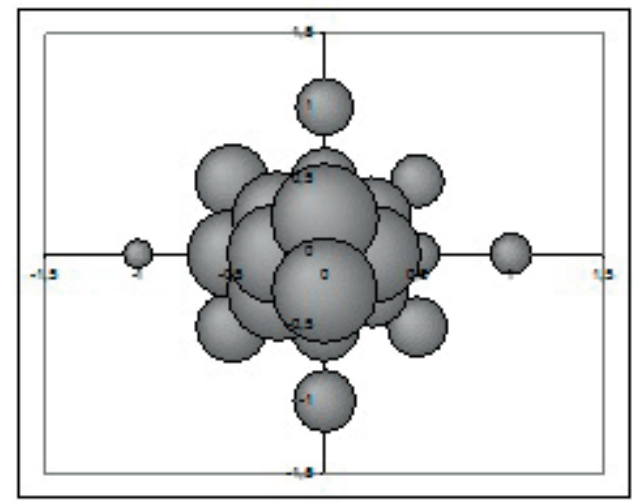

Figure 2. Figure illustrating the first 4 recurrent stages for generating a function of the following

$$
\text { form } H(x, y)=\frac{|x|^{2}+|y|^{2}}{2}
$$

Source: own study

\subsection{Application of Hölder function in studying the expansion intensity of spatial phenomena}

Multi-fractional Brownian motions in spatial terms can be used as a tool which allows to carry out multidirectional, socio-economic studies. Studying the intensity of spreading of an examined phenomenon in relation to place and time, as well as considering the short and long memory, turns out to be interesting. Using the value of Hölder function we can describe e.g. the level of environmental pollution, the effects of an explosion, spreading of a disease. We can prove that the mentioned values as well as other socio-economic characteristics are featured by memory, which means that historical observations (significantly distant or small distance away) influence current values.

In models considering spatial diffusion, the parameter of location is an important argument. In this article, this argument is a point on a plane $(x, y)$. We assume that a subset of two-dimensional space $D \in R^{2}$ (a fragment of a plane) and a range of time $T$ is given. We assume that time is a continuous parameter. We can consider the following cases:

1. A fixed point $\left(x_{0}, y_{0}\right) \in R^{2}$ (e.g. geographical coordinates). In this case we consider a stationary or non-stationary stochastic process dependent on $t$. Methods from chapter 2 are applied (for time series). In a given place $\left(x_{0}, y_{0}\right) \in R^{2}$ the process values are the values of any socio-economic characteristic, we analyze the variability of the characteristic in time on a two-dimensional chart. We study the memory of the series. For example, in the surrounding area of a given point on a plane we analyze: population density, rate of migration, level of pollution, intensity of occurrence of a certain disease unit, etc. (Figure 3). 

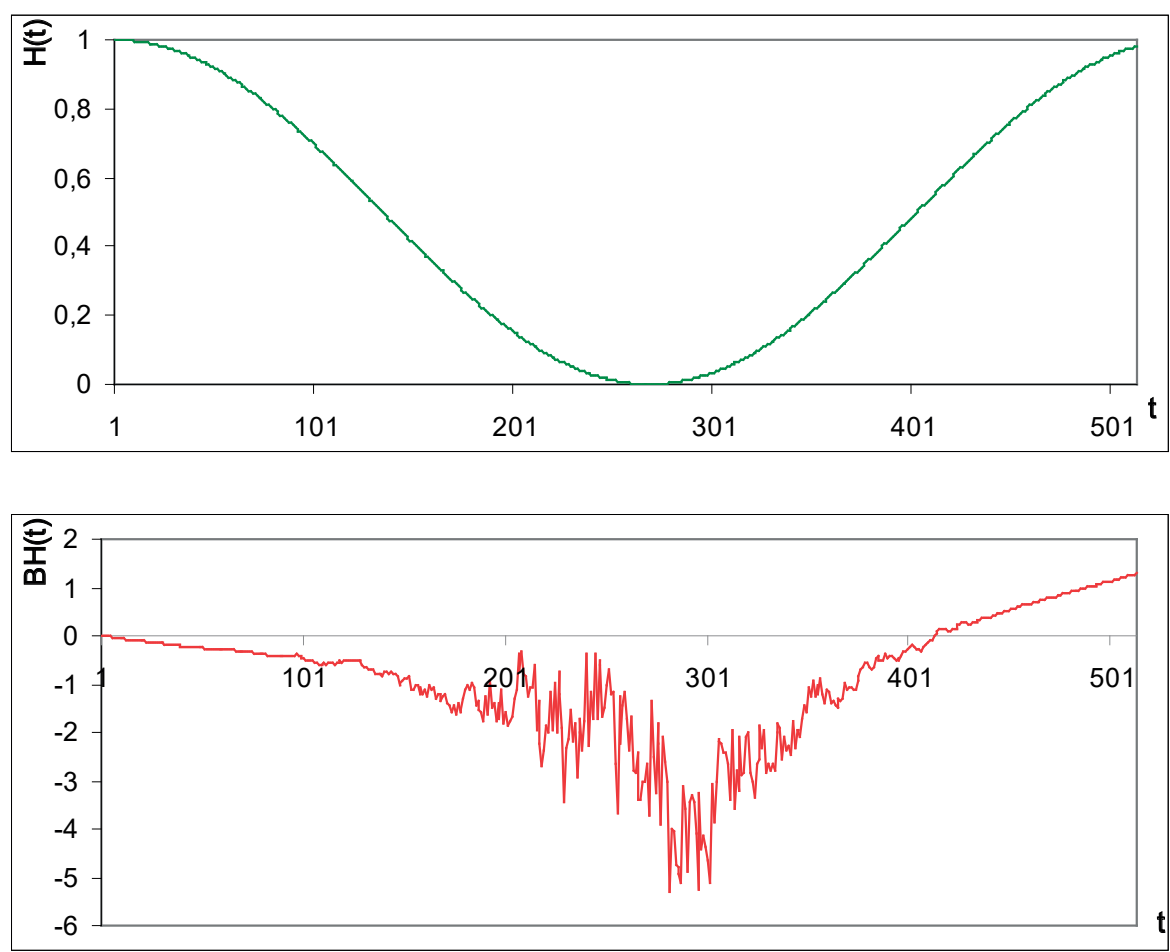

Figure 3. Simulation chart of the intensity of falling ill with a certain unit of disease at a point (on a plane) with coordinates $\left(x_{0}, y_{0}\right) \in R^{2}$ during a segment of time $T$. The lower the value of Hölder function, the more cases of the disease, $H(t)=(\cos (6 t)+1) / 2$

Source: own study

2. A fixed moment in time $t_{0} \in T$. We can construct a map of the process values in a given moment of time (scan for $t_{0}$ ). For example, the intensity of pollution in Poland on the $1^{\text {st }}$ of December, 2016 at 12.00 o'clock. With the use of levels we connect points with the same level of pollution on the map of Poland and with an appropriate intensity of grey colour we mark the level of pollution. We can then compare scans for different moments in time and observe changes taking place in time in a given area (Figure 4). 


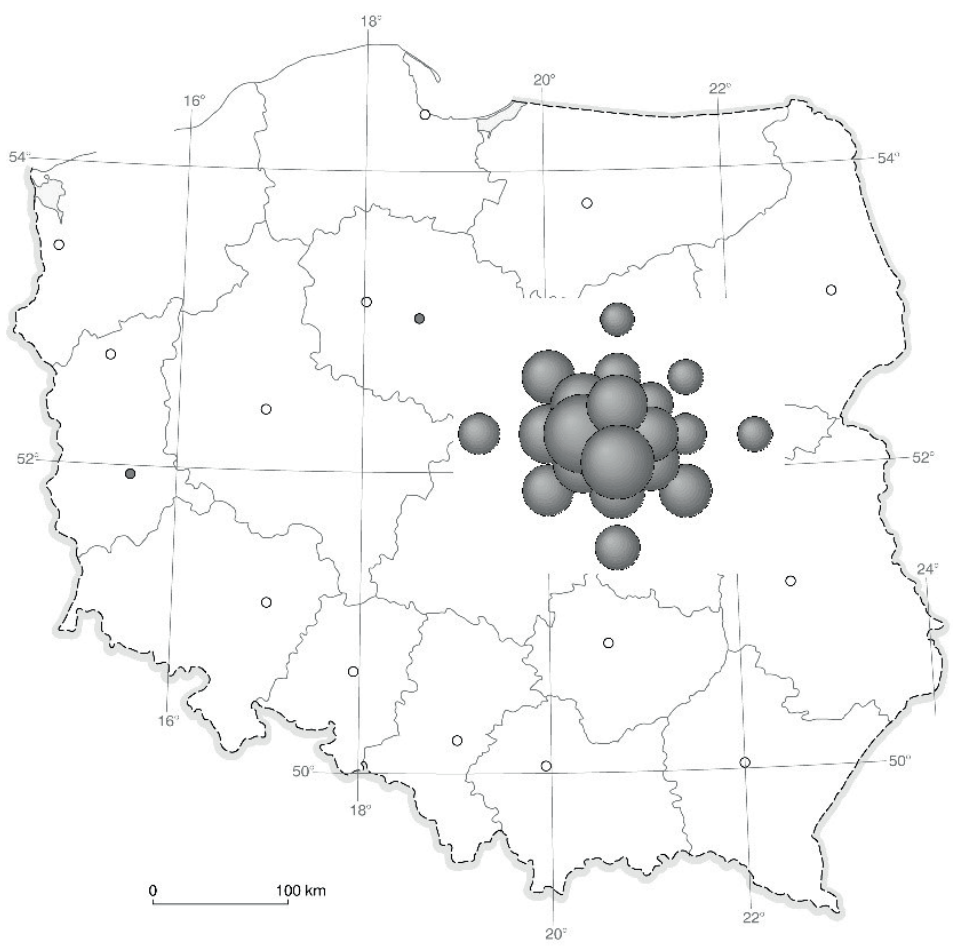

Figure 4. The effects of an explosion - the intensity of the spread of environment pollution (simulation, discreet take -4 iterations of algorithm for generating function form

$$
H(x, y)=\frac{|x|^{2}+|y|^{2}}{2}
$$

Source: own study

3. On a continuous basis (for time treated as a continuous variable) in the whole area of the analyses, changes in time and space can be illustrated via a film, where in a steady way the expansion of a given phenomenon takes place, whereas its intensity is expressed by point values of Hölder exponents with consideration of memory effect.

\section{Conclusion}

Taking advantage of methods included in the theory of stochastic processes for modelling of processes that take place in the world, in spatial terms, is a useful tool for conducting analyses. Analysis of Hölder point exponents allows us to determine in a quantitative way the level of expansion of spatial phenomena. Connecting methods of time series analysis and elements of spatial modelling is useful 
in view of the possibility of using methodology in modelling as well as analyzing the force and direction of expansion in space.

Making use of stochastic processes methods to model the structure and processes taking place in the world is currently an instrument present in theoretical and experimental considerations also in economic science. Stochastic analysis allows us to determine in a quantitative way the level of irregularity of the surface, it enables us to measure the expansion intensity of spatial phenomena. Connecting selected techniques of time series analysis and elements of spatial modelling with geometric methods is useful when considering the possibility of using methodology in economic modelling and in analysis of variability and intensity of the spread of phenomena in time and space.

\section{References}

Ayache A., Lévy-Véhel J. (1999), Generalized Multifractional Brownian Motion: Definition and Preliminary Results, [in:] M. Dekking, J. Lévy-Véhel, E. Lutton, C. Tricot (eds.), Fractals: Theory and Applications in Engineering, Springer-Verlag, New York.

Ayache A., Taqqu M.S. (2004), Multifractional processes with random exponent, "Stochastic Processes and their Applications", no. 111(1), pp. 119-156.

Baltagi B.H. (2005), Econometric Analysis of Panel Data, John Wiley \& Sons, New York.

Barrière O. (2007), Synthèse et estimation de mouvements browniens multifractionnaires et autres processus à régularité prescrite, Définition du processus autorégulé multifractionnaire et applications. PhD thesis, IRCCyN.

Bass F. (1969), A New product growth for model consumer durables, "Managment Science", no. $15(5)$, pp. $215-227$.

Box G.E.P., Jenkins G.M. (1976), Time series analysis forecasting and control, Holden-Day, San Francisco.

Daoudi K., Lévy-Véhel J., Meyer Y. (1998), Construction of continuous functions with prescribed local regularity, "Journal of Constructive Approximations", no. 014(03), pp. 349-385.

Domański R. (2002), Gospodarka przestrzenna, Wydawnictwo Naukowe PWN, Warszawa.

Echelard A., Barrière O., Lévy-Véhel J. (2010), Terrain modelling with multifractional Brownian motion and self-regulating processe, "ICCVG", no. 6374, pp. 342-351.

Falconer K.J., Lévy-Véhel J. (2008), Multifractional, multistable and other processes with prescribed local form, "Journal of Theoretical Probability", https://link.springer.com/article/10.1007/s10959-008-0147-9 [accessed: ......].

Fuller W.A. (1996), Introduction to Statistical Time Series, Wiley, New York.

Getis A., Mur J., Zoller H. (2004), Spatial Econometrics and Spatial Statistics, Palgrave Macmillan, New York.

Granger C.W.J., Mizon G.E. (1994), Nonstationary Time Series Analysis and Cointegration, Oxford University Press, New York.

Hagerstrand T. (1952), The propagation and innovation waves, "Lund Studies in Geography”, no. 4, Lund, Gleerup.

Hsiao C. (2003), Analysis of Panel Data, Cambridge University Press, Cambridge.

Kopczewska K. (2007), Ekonometria i statystyka przestrzenna, Wydawnictwo CeDeWu, Warszawa. Krugman P.R. (1991), Geography and Trade, The MIT Press, Cambridge. 
Lévy-Véhel J., Mendivil F. (2011), Multifractal and higher dimensional zeta functions, "Nonlinearity", no. 24(1), pp. 259-276.

Lévy-Véhel J., Seuret S. (2004), The 2-microlocal Formalism, Fractal Geometry and Applications, A Jubilee of Benoit Mandelbrot, "Proceedings of Symposia in Pure Mathematics", no. 72(2), pp. 153-215.

Mandelbrot B.B. (1982), The Fractal Geometry of Nature, WH Freeman \& Co, New York.

Mastalerz-Kodzis A. (2003), Modelowanie procesów na rynku kapitałowym za pomoca multifraktali, "Prace Naukowe", Akademia Ekonomiczna im. Karola Adamieckiego w Katowicach, Katowice.

Mastalerz-Kodzis A. (2016), Algorytm modelowania danych przestrzennych o zadanej lokalnej regularności, [in:] J. Mika, M. Miśkiewicz-Nawrocka (eds.), Metody i modele analiz ilościowych w ekonomii i zarzadzaniu, Wydawnictwo Uniwersytetu Ekonomicznego w Katowicach, Katowice.

Matyas L., Sevestre P. (eds.) (2006), The Econometrics of Panel Data, Kluwer Academic Publishers, Dordrecht.

Paelinck J.H.P., Klaassen L.H. (1983), Ekonometria przestrzenna, PWN, Warszawa.

Peltier R.F., Lévy-Véhel J. (1995), Multifractional Brownian Motion: Definition and Preliminary Results, INRIA Recquencourt, Rapport de recherche no. 2645.

Perfect E., Tarquis A.M., Bird N.R.A. (2009), Accuracy of generalized dimensions estimated from grayscale images using the method of moments, "Fractals", vol. 17, no. 3, pp. 351-363.

Peters E.E. (1994), Fractal Market Analysis, John Wiley and Sons, New York.

Suchecki B. (2010), Ekonometria przestrzenna, Wydawnictwo C.H. Beck, Warszawa.

Zeliaś A. (ed.) (1991), Ekonometria przestrzenna, PWE, Warszawa.

\section{Zastosowanie funkcji Höldera do badania intensywności ekspansji zjawisk przestrzennych}

Streszczenie: Rozwój metod, za pomocą których można opisać szeregi czasowe z wykorzystaniem procesów stochastycznych, nastąpił w XX wieku. Modelowano między innymi procesy stacjonarne za pomocą wykładnika Hursta, a niestacjonarne z wykorzystaniem funkcji Höldera. Cechą charakterystyczną dla tego typu procesów jest analiza pamięci występującej w szeregu. Na przełomie XX i XXI w. wzrosło zainteresowanie statystyką i ekonometrią przestrzenną, a także analizami prowadzonymi w ramach nowej ekonomii geograficznej. W artykule zaproponowano implementację metod zaczerpniętych z analizy szeregów czasowych do modelowania danych w przestrzeni oraz zastosowanie wybranych mierników do badania intensywności ekspansji zjawisk w przestrzeni. Jako miarę intensywności wykorzystuje się punktowe wykładniki Höldera. Praca składa się z dwóch części. Pierwsza zawiera opis metodyki badań, druga przykładowe zastosowania.

Słowa kluczowe: procesy stochastyczne, wykładnik Hursta, funkcja Höldera, modelowanie przestrzenne

JEL: C15, C32, C33, C51

\begin{tabular}{|l|l|}
\hline \multirow{2}{*}{ OPEN ACCESS } & $\begin{array}{l}\text { C by the author, licensee Łódź University - Łódź University Press, Łódź, Poland. } \\
\text { This article is an open access article distributed under the terms and conditions } \\
\text { of the Creative Commons Attribution license CC-BY } \\
\text { (http: //creativecommons.org/licenses/by/3.0/) }\end{array}$ \\
\cline { 2 - 2 } \\
Received: 2016-12-18; verified: 2017-10-24. Accepted: 2018-02-19
\end{tabular}

